De uil van Minerva 23 - 4 (2010)

Recensie

\title{
HEIDEGGER EN DE SUBJECTIVITEIT VAN HET SUBJECT
}

Paul Heeffer, Ontologie en subjectiviteit. Een inleiding in Sein und Zeit. Nijmegen, Vantilt, 2010, 246 blz., € 24, 95 ISBN 9789460040306

Martin Heidegger, De oorsprong van het kunstwerk. Amsterdam, Boom, 2009, 103 blz., € 8, 95 ISBN 97890 85067573

In Ontologie en Subjectiviteit - de herwerkte versie van een dissertatie waarmee Paul Heeffer in 2007 promoveerde aan het Hoger Instituut voor Wijsbegeerte van de Katholieke Universiteit Leuven - stelt de auteur zich voor de taak Heideggers Sein und Zeit uit 1927 te herlezen vanuit het gezichtspunt van de subjectiviteit van het subject. Dit lijkt aanvankelijk een eerder heikele missie, rekening houdend met de nadrukkelijke weigering van de Duitse wijsgeer zelf om de ontologische structuur van het Dasein (Erzijn) te benaderen aan de hand van de termen 'subject' en 'subjectiviteit' (zoals bijvoorbeeld in $\int 9$ van Die Grundprobleme der Phänomenologie, en $\ 13$ van Sein und Zeit). De bepaling van de zijnsaard van het Dasein als een altijd al in-de-wereld-zijn laat zich volgens Heidegger niet denken vanuit de scheiding tussen de (immanente) orde van het subject en de (transcendente) orde van het object, meer nog, ze vooronderstelt er eerder de eliminatie van. Heeffer bespreekt dit ‘buiten-zijn' van het heideggeriaanse Erzijn uitvoerig in het derde hoofdstuk van zijn proefschrift, maar de keuze voor een lectuur van Sein und Zeit vanuit de pool van het subject wordt er niet evidenter op.

De onderkenning van het mogelijks bevreemdende karakter van de opzet van Ontologie en Subjectiviteit in de introductie is derhalve niet overbodig. Heeffer ontslaat zich ook niet van de plicht zijn keuze voor het gebruik van de termen 'subject' en 'subjectiviteit' te verantwoorden: ten eerste om de continuïteit aan te geven met de problematiek van het subject sinds de $17^{\mathrm{de}}$ eeuw, en ten tweede omdat de term Dasein niet overal ingang heeft gevonden (blz. 13). In de marge zou men kunnen opmerken dat Heidegger met zijn bewuste keuze voor de term Dasein wellicht eerder een cesuur heeft willen betekenen in het filosofische denken over de menselijke zijnsaard, en dat het eerste deel van Heeffers verantwoording daarom misschien niet helemaal overtuigt. 
In het proefschrift vertrekt de auteur vanuit twee (interafhankelijke) vragen: in een eerste beweging bevraagt hij hoe het onderzoek naar de ontologische structuur van het zijn in Sein und Zeit een nieuwe articulatie toelaat van de subjectiviteit van het subject, om in tweede instantie de implicaties van deze analyse na te gaan op de algemene opzet van Heideggers opus magnum (blz. 12). Het grootste deel van het werk beoogt een thematisering van het eerste luik; pas in de laatste paragraaf van het laatste hoofdstuk mondt Ontologie en Subjectiviteit uit in een nieuw perspectief op het onvoltooide karakter van Sein und Zeit, onvoltooid omdat Heidegger er uiteindelijk nooit toe zou komen een antwoord te formuleren op de hoofdvraag naar de aard van het zijn zonder meer.

De eerste vier delen van Ontologie en Subjectiviteit bieden een gestructureerde inleiding op Sein und Seit, zoals beloofd op de achterflap. Het eerste hoofdstuk kadert de vraag naar het zijn van het erzijn binnen de overkoepelende fundamenteel-ontologische opzet van Heideggers werk uit 1927 om een antwoord te bieden op de vraag wat het zijn is. Vanuit de ontologische differentiatie tussen zijn en zijnden (het ontologische en het ontische), en de bepaling van het a priori karakter van het zijn als datgene wat in de verhouding tot het zijnde altijd-reeds werd begrepen onder de vorm van een zijnsverstaan, schetst Heeffer Heideggers particuliere hermeneutische benadering van de zijnsvraag: het onderzoek naar het zijn zelf, vangt noodzakelijk aan bij een voorbereidende analyse van de zijnsstructuur van het Dasein, omdat daarin het zijnsverstaan reeds noodzakelijk is gegeven. Met Heeffer: "Als erzijn kunnen we enkel existeren, voor zover we zoiets als existentie - het zijn van het erzijn - altijd reeds hebben verstaan" (blz. 23). Een analyse van de existentialen van het zijn van het erzijn moet zo een benadering mogelijk maken van het zijn zonder meer.

Deze methodische overwegingen, die Heidegger noopten tot zijn 'voorbereidende fundamentele analyse van het erzijn', vormen het uitgangspunt van het laatste hoofdstuk van Ontologie en Subjectiviteit, waar Heeffer argumenteert dat de resultaten van deze voorbereidende analyse de grenzen blootleggen van het onderzoek naar het zijn zonder meer: vanuit de geworpenheid van het vragende zelf laat een antwoord op de zijnsvraag zich niet denken (blz. 241) (Cfr. de tweede onderzoeksvraag).

Alvorens tot die conclusie te komen legt Heeffer nog een heel parcours af doorheen het onherbergzame landschap dat Sein und Zeit vaak is; een parcours dat gaandeweg duidelijk zou moeten maken hoe de analyse van het zijn van het Dasein nieuwe mogelijkheden opent om de subjectiviteit van het 
subject te denken: van de bepaling van het Dasein in termen van existentie en telkenmijnigheid (hoofdstuk 2), over de karakterisering van haar zijnsaard aan de hand van intentionaliteit, transcendentie en (tijdiging van oorspronkelijke) tijdelijkheid (hoofdstuk 3), tot en met Heideggers invulling van de zelfheid als existentiaal (hoofdstuk 4). Deze hoofdstukken lijken een samenvatting te zijn van Sein und Seit - op zich een puike prestatie - maar soms lijkt de auteur danig opgeslokt door de complexe argumentatiestijl en weerbarstige terminologie van de Duitse filosoof dat hij nauwelijks nog komt tot een terugkoppeling naar zijn initiële vraagstelling. Er wordt eigenlijk weinig toegevoegd aan de oorspronkelijke tekst, een aantal paragrafen bestaat bijna volledig uit een aaneenschakeling van citaten, en kritische noten zijn schaars tot het einde van het voorlaatste hoofdstuk.

De lezer wordt dan wel vergast op de verdienstelijke neerslag van een duidelijk ingespannen lectuur van Sein und Zeit, maar met betrekking tot de aangekondigde opzet blijft hij wat op zijn honger zitten. De auteur stelt nooit echt scherp hoe het onderzoek naar de ontologische structuur van het Dasein een vernieuwend subjectbegrip en een andere benadering van subjectiviteit met zich meebrengt. De loutere herhaling van Heideggers kritiek op de manier waarop het subject werd gedacht bij onder meer Descartes en Husserl in het tweede en derde hoofstuk van Ontologie en Subjectiviteit kan de honger niet stillen.

Vanuit deze laatste bedenkingen zijn de eerste paragrafen van het slothoofdstuk (De geworpenheid van het erzijn) op zijn minst verrassend te noemen: de lezer krijgt een wat meer afstandelijk en kritisch perspectief op Sein und Zeit aangeboden - en misschien ook wat meer ademruimte - en de filosoof Heeffer lijkt voor het eerst kleur te bekennen. In dit vijfde hoofdstuk tracht de auteur meer grip te krijgen op de existentiële ervaring doorheen een uitwerking van de heideggeriaanse 'geworpenheid' aan de hand van Levinas' analyse van de misselijkheid - walging zo men wil - in L'évasion (1935), een werkje van amper twintig bladzijden. Heidegger zelf stelde de ervaring van onmacht tegenover de eigen existentie in de geworpenheid van het Dasein volgens de auteur niet voldoende scherp, vandaar de keuze om in Ontologie en Subjectiviteit op de valreep een ommetje te maken langsheen de 'malaise' van de Levinas. Maar, zo voegt Heeffer er fijntjes aan toe: daarbij begrijpen we Levinas ongetwijfeld anders dan bijzelf zou hebben gewild (blz. 206). Die laatste frase blijft misschien gedurende het laatste hoofdstuk wat op de lever liggen, zeker met de gespannen verhouding tussen Heidegger en Levinas in het achterhoofd, al moet het gezegd dat dit onderdeeltje leest als een trein, en Heeffers opwelling van filosofische stoutmoedigheid smaakt naar meer. 
Ontologie en Subjectiviteit blijkt op het einde van de rit een prima inleiding in Heideggers Sein und Zeit, maar slaagt er evenwel niet overtuigend in om de verwachtingen (geschapen in de introductie) bevredigend in te lossen.

Tot slot: voor de liefhebbers zij opgemerkt dat uitgeverij Boom niet zo lang geleden een gloednieuwe, zeer goede vertaling uitbracht van Heideggers De oorsprong van het kunstwerk van de hand van Mark Wildschut en Chris Bremmers. Zoals bekend gaat het hier om de neerslag van drie lezingen die Heidegger in 1936 verzorgde omtrent de 'wezensherkomst' [Wesensherkunft] van het kunstwerk, namelijk 'Het ding en het werk', 'Het werk en de waarheid', en 'De waarheid en de kunst'. De vertaling volgt de versie van Der Ursprung des Kunstwerkes zoals die is verschenen in deel vijf van de Gesamtausgabe van het oeuvre van de Duitse filosoof uit 1987, en wordt ingeleid door Hans-Georg Gadamer, die onder andere Heideggers belangstelling voor de ontologische structuur van het kunstwerk situeert in de totaliteit van het Heideggeriaanse project "om het zijn zelf als een geschieden van waarheid te begrijpen." 
